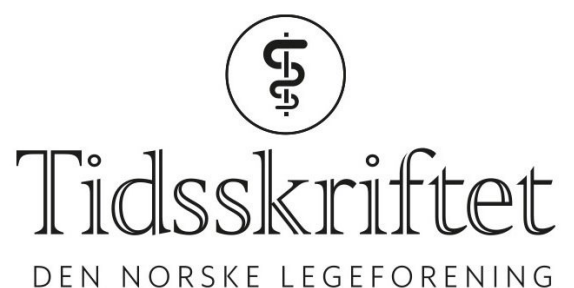

DEN NORSKE LEGEFORENING

\title{
Hva lærte politikere av innføringen av mammografiscreening?
}

KOMMENTAR

\section{PER-HENRIK ZAHL}

E-post: per-henrik.zahl@fhi.no

Per-Henrik Zahl er seniorforsker ved Folkehelseinstituttet. Ingen oppgitte interessekonflikter.

Marit Solbjør finner at det var et underliggende premiss i stortingsdebatten om mammografiscreening i 1998 «at tidlige funn påvirker brystkreftdødeligheten» (1). Tidlige funn betyr at man oppdager flere små svulster uten spredning, men screening endret ikke forekomsten av brystkreft med spredning. Siden screening ikke forebygget spredning ved diagnose, så kan screening umulig redusere dødelighet av sykdommen. All økning i forekomst ved screening som ikke forebygger spredning, kalles overdiagnostikk $(2,3)$. I ettertid er det interessant å studere om politikere lærte noe om betydningen av overdiagnostikk av kreft.

Først er det er interessant å notere at Stortinget ikke ble informert om at det var stor skepsis blant patologer til mammografiscreening på grunn av studier som hadde vist at spredning starter lenge før brystkreft kunne oppdages med mammografi (4). Spredning starter etter 10-20 volumdoblinger av svulsten, mens mammografi kan oppdage svulster først etter 30 volumdoblinger (og kan oppdages klinisk etter 32 volumdoblinger). Dessuten vokser svulster så raskt at de blir oppdaget mellom to screeninger, slik at i snitt fremskynder screening diagnosen med én doblingstid (og dette er 10-20 doblingstider etter at spredning har startet)(2).

Året etter behandlingen i Stortinget kom rapporter som påviste alvorlige feil i de studiene som viste 30 \% reduksjon i dødelighet av brystkreft ved screening. Kvinner var selektivt ekskludert og dødsårsaker var forandret, alt til fordel for mammografiscreening. De mest troverdige studiene viste ingen reduksjon i dødelighet (5).

I 2015 ble pakkeforløpet ved behandling kreft innført. Formålet med pakkeforløpet er at kreftpasienter skal oppleve et godt organisert og forutsigbart forløp uten unødvendig ikkemedisinsk begrunnet forsinkelse i utredning, diagnostikk og behandling. Over halvparten av det som oppdages ved PSA- og mammografiscreening er overdiagnostikk $(2,3)$. Overdiagnostikk medfører overbehandling og noen dør av overbehandling. Pasienter som er overdiagnostisert, bør ikke følge et pakkeforløp. Man bør heller studere om de lever lenger med aktive overvåking. Dette gjøres for prostatakreft (6) og bør gjøres for brystkreft. Overdiagnostikk og behandling er vanskelig å forklare til pasienter, men politikere bør forstå begrepene. Innføringen av pakkeforløp for kreft minner mye om innføringen av mammografiscreening. 
LITTERATUR:

1. Solbjør M. Stortingsdebattene om mammografiscreening i 1998. Tidsskr Nor Legeforen 2018; 138: doi: 10.4045/tidsskr.17.1049. [PubMed][CrossRef]

2. Zahl P-H, Jørgensen KJ, Gøtzsche PC. Overestimated lead times in cancer screening has led to substantial underestimation of overdiagnosis. Br J Cancer 2013; 109: 2014 - 9. [PubMed][CrossRef]

3. Jørgensen KJ, Gøtzsche PC, Kalager M et al. Breast Cancer Screening in Denmark: A Cohort Study of Tumor Size and Overdiagnosis. Ann Intern Med 2017; 166: 313 - 23. [PubMed][CrossRef]

4. Spratt JS, Greenberg RA, Heuser LS. Geometry, growth rates, and duration of cancer and carcinoma in situ of the breast before detection by screening. Cancer Res 1986; 46: 970 - 4. [PubMed]

5. Gøtzsche PC, Olsen O. Is screening for breast cancer with mammography justifiable? Lancet 20oo; 355: 129-34. [PubMed][CrossRef]

6. ProtecT Study Group. 10-Year Outcomes after Monitoring, Surgery, or Radiotherapy for Localized Prostate Cancer. N Engl J Med 2016; 375: 1415 - 24. [PubMed][CrossRef]

Publisert: 20. august 2018. Tidsskr Nor Legeforen. DOI: 10.4045/tidsskr.18.0550

(C) Tidsskrift for Den norske legeforening 2020. Lastet ned fra tidsskriftet.no 